\title{
Group Investigation and Explicit learning Models in Learning Physics at Senior High Schools
}

\author{
I Wayan Santyasa ${ }^{\text {a) }}$, I Nyoman Kanca ${ }^{\text {b) }}$ I Wayan Sukra Warpala ${ }^{\text {c) }}$, \\ I Komang Sudarma ${ }^{\mathrm{d})}$
}

\author{
Postgraduated Program, Universitas Pendidikan Ganesha, Sukksma, Indonesia

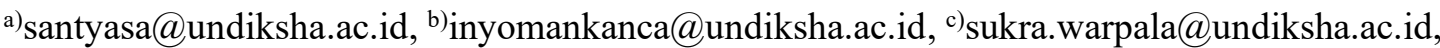 \\ d)ikomangsudarma@undiksha.ac.id
}

\begin{abstract}
Physics teaching in high school is still dominated by explicit learning models, relatively rarely empowering the potential of group inquiry based on social interaction. It has become one of the reasons for the lack of optimal student learning products. This study aimed to analyze the difference of effect between the group investigation (GI) model and the explicit learning (EL) model in achieving critical thinking skills, social attitude, spiritual attitudes, and student character in learning physics. To achieve this goal, a quasi-experimental study was conducted using a nonequivalence posttest only control group design. The study population was 16 classes (566 people) XI MIPA class students who came from two SMAs, namely eight classes (280 students) SMA 1 Tabanan and eight classes (286 students) SMA 1 Kediri Tabanan. The sample in each high school consisted of 2 classes selected by a random assignment technique. The whole sample was four classes (140 students, or $24.73 \%$ of the total population), two classes learned with the GI model and two classes with the EL model, each learned sound wave and lightwave. Data on students' critical thinking skills was collected by 12 items test. Data on students' social attitude, spiritual attitude, and character were collected with a social attitude questionnaire which consists of 30 items, a spiritual attitude questionnaire which consists of 30 items, and a character questionnaire that consists of 18 items. The research data were analyzed by one way MANOVA. The results showed that the GI model had a higher effect than the EL model in achieving critical thinking skills, social attitude, spiritual attitude, and the character of the students in learning sound waves and lightwave in high school physics.
\end{abstract}

Keywords: GI and EL models, critical thinking, social attitude, spiritual attitude, character

\section{INTRODUCTION}

Success in teaching practices have characteristics that are supported by some very varied perspectives (Heinich et al., 2002), namely student active participation. Practice, individual difference, feedback, realistic contexts, and social interaction. The six perspectives are the basis of cooperative learning (Santyasa, 2017) which can be explained as follows.1) Student active participation. The teaching runs effectively if the students are actively involved in meaningful tasks and are actively interacting with the message (content) of the teaching 2) Practice. The practice in the varied conditions will give support to the occurrence of what was learned. This perspective will give support to the occurrence of improvement in the ability to apply new knowledge, skill, and attitude and retention. 
3) Individual difference. The teaching that is implemented can be said to be effective if it can accommodate differences concerning the personal skill, general attitude, and prior knowledge.4) Feedback; in a teaching practice it is very important to give feedback to know the students' position about the task that is being done. 5) Realistic context. The students will easily remember and apply the knowledge that has been obtained if the knowledge is related to the real-world context. 6) Social interaction. This is concerned with the students' ability as a member of the group and /or peer tutor to provide pedagogy and social support.

One of the cooperative learning models that are accommodative to the six perspectives above is a group investigation (GI) model. Learning through a GI group can involve students actively through their mental processes and minimize differences among individuals, and negative effects that arise from competitive learning condition (unhealthy learning competition). As a soft technology, GI has the synergistic effect of the opportunity for the development of social skills between formal and non-formal education. The integration of the opportunity can be seen from (1) the realization that practices in the life outside the class require skills and collaborative activities starting from inside the group (team) in the workplace into the daily social life; (2) the growth and development of physical and mental awareness of social interactional values to realize meaningful learning. The two propositions indicate that GI has the potential as the means for the students to develop good spiritual attitudes and characters.

Because of the importance of the GI model in teaching, up to this moment, this model has been tested for its superiority in teaching. The GI model can improve the students' achievement in vocational schools (Sangaji, 2016). The implementation of GI in language teaching, especially in developing writing skills, has been tested for its superiority (Pitoyo et al., 2014); it is also superior in developing speaking competence (Ahsanah 2015; Iswardati 2016). In mathematics teaching at junior high school, Indarti et al. (2018) have shown that the GI model is better than the explicit learning (EL) model in the attainment of learning achievement.

In Physics teaching at senior high school, GI has shown to be better than explicit learning model (EL) in the attainment of learning achievement (Astiti 2018; Sari, 2017), in attainment of conceptual understanding (Yuandini and Sahyar, 2017), in the attainment of concept understanding and process skill in physics in the topics of material, temperature and heat (Parinduri et al., 2017). GI model has been tested for its effectiveness compared to the EL model with the first-semester university students by AKÇAY and DOYMUŞ (2012). They stated that in a physics course in the motion and force, the students who learned with the GI model showed a better learning achievement than those who learned with the EL model.

In Bali province, the potentiality of the GI model has not yet been largely exposed to senior high school. The results of a survey in Bali, which was conducted by Santyasa et al. (2014) and Santyasa et al., 2015), show that physics teachers at high schools tend to dominate the teaching. Other findings also reveal that the teaching done by the teachers in which the teacher explains and the students listen and take a note still dominate in the teaching of physics at senior high school (Santyasa et al., 2014; Santyasa \& Suwindra, 2009). Teachers tend to think that a lesson has not yet ended if all the curriculum materials have not yet been taught to the students. In this teaching model, information that is presented by the teacher is thought to be fully accessible by the students only if it can be remembered, understood and applied in a new situation (Dostál 2015). In other words, the teaching practice that is teachercentered aims only at the attainment of the curriculum contents. Neo and Tse Kian (2003) call this traditional teaching, in which the teacher tends to stress factual knowledge and focuses on the delivery of content knowledge. Teacher centered teaching is often called explicit learning model (EL) https://en.wikipedia.org/wiki/Direct_instruction). The EL model uses more lecturing or materials demonstrations to the students. The implementation of the EL model in physics teaching is one of the causes of the difficulty of reaching the educational objectives optimally.

Physics teaching in high school is not only about concepts and principles, but it is also about process and attitude. Recently, the studies that were related to physics show that teacher-centered learning (TCL) cannot adequately educate students. One of the TCL models is explicit learning (EL). EL model can generally facilitate students to learn physics superficially (McDermott \& Redish 1999 in AKÇAY1 \& DOYMUŞ 2012). The superficial physics teaching process leads to a less than optimal learning product, including the difficulty of acquiring critical thinking skills. The nurturing effects include the relatively difficult way to develop a social and spiritual attitude, including a good character in physics 
teaching. Hence, physics teachers should implement a student-centered learning (SCL) model. GI is one of the student-centered learning models.

In light of the background above, this study focused attention on studying the difference in the effect of GI model compared to EL model in the attainment of critical thinking skill, social attitude, spiritual attitude, and students' character in physics teaching in the eleventh grade at SMAs ( senior high schools).

\section{GI Model}

The idea about a group investigation learning model started from the philosophical perspective about the concept of learning. To be able to learn, an individual has to have a partner or friend. In 1916 John Dewey wrote a book entitled Democracy and Education (Santyasa, 2017). In that book, Dewey developed the concept of education, that class has to be the reflection of society and serves as the laboratory to learn about real life. Dewey's main ideas about education were (1) the students have to be active; learning is by doing; (2) learning should be based on intrinsic motivation; (3) knowledge is developing, is not static; (4) learning activity has to match the student's need and interest to learn; (5) education has to cover learning activities that cover the principle of mutual understanding and mutual respect, which means the democratic procedure is crucial; (6) learning activities are related to the real world.

The development of GI learning is based on a premise that learning process at school is concerned with the zone in the social and intellectual domain, and the process that occurs is the combining of both values; (Achmad et al., 2018; Santyasa, 2017; Siddiqui, 2013). Therefore, group investigation cannot be implemented in an educational environment that cannot support the occurrence of impersonal dialogues ( or do not refer to the socio-affective dimension of teaching). The socio-affective group, intellectual exchange, and meaningful materials are the primary sources that are reasonably important in giving support to the students' learning efforts. Interactional communication that is cooperative between the students in a class can be achieved well if the teaching is done through small learning groups.

GI learning model is very suitable for the field of study that needs integrated project study activities including physics teaching that is oriented to the acquisition, analysis, and information synthesis in the effort to solve a problem. Thus, success in implementing GI cooperative technique depends very much on initial training in mastering communication and social skills. The academic tasks have to be oriented to the giving of an opportunity to group members to give various contributions, not only designed to get the answer to factual questions (what, who, where, or the like). GI cooperative learning model is very ideal for use in physics teaching.

Generally, the planning of classroom organization using GI learning model is as follows: groups are formed by the students themselves, each consisting of 2 to 6 members, each group is free to choose a subtopic from the whole material unit (topic which will be taught, and then the group makes or produces the group report. After that, every group presents or displays their report to the whole class, to share information with their friends.

According to Slavin (1995) and Santyasa (2017), the stages in GI learning are as follows:(1) identifying a topic and organizing students into groups; (2) planning learning tasks; (3) doing a simple investigation; (4) group discussion to prepare the final report; (5) representing the final report (in-class discussion); and (6) evaluation.

GI learning model needs to be promoted to overcome the effect of competitive learning that has negative effects on students' psychological development. They have to feel that they share the responsibility to achieve learning objectives. The structure of the goal of GI is characterized with a reasonably high degree of interdependence among the students in their group to achieve success in the learning practices.

Hence, the developing social system is the presence of a democratic learning interaction among the students and between the group of students and the teacher based on agreements, the teacher's direction to the students has to be made as minimal as possible, and the students and the teacher have an equal status in facing and solving problems. 
The supporting facilities of GI learning model are (1) printed material such as textbook, and student's worksheet, and learning guidebook for students and teacher's book; (2) suitable research instruments ( for example, an environment that is rich with learning resources); (3) tables and chairs and other classroom furniture that are easily moved around or a classroom that has been set for group discussion.

A teaching practice that puts an emphasis on problem-solving (real-world or simulated problem) and the provision of a multi-site learning environments need cooperation among the students. This is a scaffolding in the learning process to solve problems through peer collaboration with more competent peers. In this process knowledge and skill construction is shared among the students (not from the teacher and a textbook only) In addition, this process also directs the development of cooperation in the team as required in real life. The implementation of cooperative learning can accelerate the acquisition of some core skills, such as cognitive skill, affective skill, critical thinking, and this has an impact on achievement, social attitude, spiritual attitude and character. With the student lead discussion working principle, especially for students with low achievement, the use of cooperative learning can increase their academic motivation and social values such as sensitivity and tolerance.

\section{EL Model}

The term explicit learning (EL) is related to the instructional approach and curriculum material developed by Sigmund Freud and Carl Rogers at the end of the 1960's (Luke, 2014). The teaching is done as something special and explicit, based on a stimulus/ response classical behavioral conditioning developed by B. F. Skinner. The teaching program provides the teachers and the school with a linear programmed model. The teacher follows a step by step approach, lesson by lesson according to the sequence of skills that has been determined and then these are given to the students. The approach determined for teaching is quick and linear and is aimed to maximize the time precision in doing the task, and positively strengthening the students' behavior. The teacher gives a rigid training by following the teacher's guidebook. The teacher focuses more on the effort to present the curriculum material. The presentation of the material is followed by the assignment of tasks, the giving of a test, and evaluation that closely follow the teaching objectives that have been determined before. Feedbacks are given to the result of evaluation to change the behavior, to group abilities, and to give more stress on academic skill. Operationally, the DI model is implemented with the following steps: motivating the students, giving the teaching material, making student groups, having the students to learn in groups, asking the students to evaluate the students' reports.

\section{Critical Thinking}

Critical thinking is "logical reflective thinking that focuses on deciding what has to be trusted or done (Ennis 2013). In deciding this and done an individual is helped with a set of critical thinking skills. KARAKOC (2016) states that when the students think critically, they are motivated to think for themselves, formulating a hypothesis, analyzing and synthesizing events, to explore further by developing new hypotheses and testing them based on empirical facts. In other words, the students think critically like scientists who are doing research, formulating questions, refusing information, are active, thinking analytically and synthetically, evaluating information, and explaining things correctly, have open minds and aware of their thinking processes. Every student has to have an effective critical thinking skill, and should not accept what the teacher says. Hence, the teacher has to critically give learning facilities that can motivate the students to think critically. One of the ways that can facilitate the students in developing critical thinking skills is the GI learning model.

\section{Social Attitude}

Social attitudes are part of interpersonal intelligence. Social attitudes consist of 4 ( four) main types (Gardner 1999; Goleman 2000; Howarth 2006), namely (1) group regulating attitude, (2) solution negotiating attitude, (3) personal relation maintaining attitude, and (4) social analyzing attitude. 
A group regulating attitude is a social attitude that is often needed by students in learning. Included in this attitude is the tendency to start and coordinate efforts to make people move. Solution negotiating attitude is seen in the aptitude of a mediator in preventing conflicts or settling a conflict that is breaking out. This attitude is the basis for reaching an agreement, in overcoming or preventing a dispute, is competence in diplomacy and law that makes a person able to settle a dispute. The attitude to build personal relations is often called the ability to show empathy and develop relations. This attitude makes an individual easy to enter into an association or to recognize and respond appropriately to other's feelings and concerns. The student with this attitude is "the team player" that is dependable, a partner who can be trusted, a loyal business partner. In the business world, he or she is successful as a salesperson or manager or can become a great teacher. The social analyzing attitude is the tendency to able to detect and has an understanding of other's feelings, motifs, and concerns. Understanding others causes a pleasurable intimacy or solidarity. In its best form, this ability can make an individual a competent therapist or counselor.

\section{Spiritual Attitude}

On the importance of spirituality in education, Egan (2001) states that education is an effort to maximize students' acquisition of cultural artifacts produced by other people, so that they become what might be called, although less adequately, cognitive tools. The more we have the education to understand the world and experiences, the better our chances to appreciate the vision of human experiences which collectively we call spirituality. Egan's view shows that the world and its contents are not only to be seen with the cognitive tool, but this has to involve another ability, which is the spiritual attitude. Then Egan proposes five components in developing the students' spiritual attitude: (1) motivating the students to improve their understanding and belief about the world and their experiences; (2) introducing them to the ways human beings have been struggling for life based on intense experiences; (3) introducing them to good deeds, such as carefulness, alertness, and enthusiasm in observation, and pleasure in inventing process ; (4) motivating them to feel a pleasure in sacrificing themselves for other's goodness; and (5) inviting them to understand inventions in the past and how to develop them in the future. While De Jager Meezenbroek et al. (2012) identify eight dimensions of spiritual attitude: 1) meaningfulness 2) trust, 3) acceptance, 4) awareness of the current period, 5) care for others, 6) harmony with nature, 7) ) transcendent experience, 8) spiritual activities.

Based on the explanation above, the dimensions of spiritual attitude can be summed up as follows: living a meaningful and harmonious life; being happy, being peaceful with others, having a personal context that is oriented to the community, loving the environment, respecting variety, talking positively, talking honestly; having a positive aim in a group life; offering a good healing to others, loving God, having a personal relation with God, having solidarity with other people, believing other people, believing in God.

\section{Character Education}

Character education is defined as an effort to consider the development of virtues (Lichona, 1999). According to Yahya (2010:1), character education teaches the habit in the way of thinking and behaving that helps the individuals to live and cooperate as a family, community, and nation and help them to make accountable decisions. Besides, Raka et al. (2011:xi) state that character education is needed in order for every individual becomes a better person, a better community member, and a better citizen. The three opinions above are not so different. In principle, character education is crucial to formulate and implement to develop virtues in the community. Virtue is objectively a good human quality, good in development, good in the individual life, and community life. Because it is intrinsically good, a virtue transcends time and culture; a virtuous person always possesses justice, honesty, and kindness. Character education is a developing discipline to optimize students' ethical behaviors (Agboola \& Tsai 2012).

Character education at school has the aim to develop 3 (three) things: (1) good people with good characters; (2) good schools as good places for developing good characters; and (3) good and morally good community members. The attainment of the first aim is made to direct in order all people have good characters. Educational objectives can be achieved if individuals, families, schools, communities 
and places of worship can function optimally as the nurseries for good characters. Besides, character education will be successful following the support from the national education system, in which the government has to have commitment and responsibility (Fathurahman 2012). With policies that are certain and supportive, this atmosphere will become conducive to the operational level. Teachers and students will get support in the form of adequate facilities. Character education does not only helps the students to develop good characters, but it also develops a social attitude and good emotional attitude.

Suyanto (2010), states that there are 10 (ten) pillars of character that are derived from the universal good values, namely (1) love for God and all of His creations, (2) autonomy and responsibility, (3) honesty/ trustfulness, (4) diplomacy, (5) respectfulness and politeness, (6) generosity, showing a love for helping others and cooperation with other people, (7) self- confidence and hard-working, (8) leadership and justice, (9) goodness and humility, and (10) tolerance, peacefulness, and unity.

The formulation of character education above is very important as a reference in designing instruction and evaluating the instruction with character education content. Previous studies have presented relevant findings in the increase in social and emotional skill and attitude, behavior, and the results that are related to success in school resulted from the social and emotional interventions through character education (Dodds 2016). Character education supports the role of the school to serve as a place to educate students to develop respect, responsibility, honesty, trust, positive relations, care, justice, integrity, and good citizenship.

\section{METHODS}

\section{Research Design, Population, and Sample}

This study was a quasi-experimental study with a nonequivalence posttest only control group design. The population consisted of 16 classes (566 students) of XI MIPA classes from two SMAN's, namely SMA Negeri 1 Tabanan with eight classes or 280 students and SMA Negeri 1 Kediri Tabanan with eight classes or 286 students. The sample was drawn using a random assignment to determine 2 sample classes in each school. Based on this technique, from SMA Negeri 1 Tabanan was selected Class XI MIPA 1 (35 students) who learned with the GI model and Class XI MIPA 2 (35 students) who learned with the EL model. From SMA Negeri 1 Kediri was selected Class XI MIPA 2 (35 students) who learned with the GI model and Class XI MIPA 5 (35 students) who learned with the EL model. Thus, the size of the whole sample was four classes (140 students or $24.73 \%$ of the population), two classes who learned with GI and two other classes who learned with the EL model. The topics selected as the objects of the study were sound wave and lightwave.

\section{Research Treatment}

Research treatment was given five times in a face to face meeting with a duration of 3 periods. At every meeting, the treatment was given in 3 stages, namely pre-activity during activity, and closure. At the GI model treatment, the pre-activity which was done by the teacher consisted of greeting, checking students' attendance and readiness to learn, informing the students about Standard Competency, Basic Competencies, and learning indicators which the teacher wanted to achieve, dividing the students into 7 heterogeneous groups with high, medium, and low abilities in each group.

The while activity in the GI model consisted of some stages:1) Preview, Question, and Read with students' activities of (a) learning problems related to the concepts of sound wave and lightwave presented in the form of student's worksheet; (b) receiving guidance from the teacher in analyzing problems that were suitable with the students' prior knowledge; (c) in groups, collecting data/ information from various resources (literature/the internet) about the concept of sound wave and lightwave that are presented in the students' worksheet; and (d) reading literature/ the internet to find the concepts of sound wave and lightwave. 2) Reflect, on the students' activities as follows. (a) taking a note / a summary of the problem given and writing it in the student's worksheet; (b) discussing the result obtained in the group. Besides, the teacher also observed the students in their groups; 3) Recite, with the students' activities as follows: (a) the students presented the result of the group discussion; 
then they presented the result of investigation based on the problem learned; (b) the students collected the result of their group discussion that has been revised based on a class discussion. 4) Review, with the students' activities as follows: doing a written quiz individually. The closure in the GI model consisted of the following activities:(a) the teacher concluded the lesson ; (b) the teacher assigned the students a homework as enrichment; (c) the teacher informed the students about the topic for the next meeting, and (d) the teacher ended the lesson with a leave-taking.

In the EL model treatment, the pre-activity done by the teacher consisted of opening the lesson by greeting, checking the students' attendance; informing the students about the Standard Competency and Basic Competencies, Indicators and the teaching objective; motivating the students to explore the benefits of learning sound wave and lightwave.

In the while activity, the EL model was implemented by the teacher with the steps: 1) explaining the topic of the concept of sound wave and lightwave; 2) explaining the topic stage by stage; 3) asking the students about the concepts that have been explained; 4) distributing student's worksheets to the class groups; 5) asking the students to collect the results of discussion that have been written in the group reports; and 6) motivating the students who were less active in the groups

In the closure of the EL model, the teacher followed the steps: asking the students again about the material that they have not understood, asking some students to conclude some major points learned, and informing the students about the topic of the next meeting.

In the sixth meeting, the students in GI and EL groups did the test of the critical thinking skill in 100 minutes. For the next 30 minutes, the students in the two groups of treatment answered a questionnaire of social attitude, spiritual attitude, and character attitude.

\section{Research Instruments}

\section{Critical thinking test}

The critical thinking skill test was decided to have 12 items. The test material covered nine subtopics. The number of items in each subtopic and the classifications of the critical thinking skill are 1) physical characteristics of sound wave, consisting of 1 item which formulates the problem; 2) the spread of sound wave and its application, consisting of one item which gives an argument and another which does a deduction, 3) the Doppler effect which consists of one item which formulates the problem and another which makes a decision and implements it, 4) the wave of an organ string and pipe which consists of one item which does an induction and another which does an evaluation; 5) the sound intensity and the degree of intensity of sound with one item which makes a decision and implements it; 6) light dispersion with 1 item which gives an argument, 7) the reflection and refraction of the light with 1 item which does a deduction, 8) light interference with 1 item which does an induction and 9) light polarization with 1 item which does an evaluation.

The critical thinking test was made in the form of an essay test with the rubric of each item using the 0-5 scales, while the questionnaire uses the 1-4 scale. The result of a try-out determined 12 items of the critical thinking skill instrument to be used in collecting the data. The determination index of the instrument ranges from 0.21 to 0.50 , the item difficulty index from 0.37 to 0.70 , and the item-total correlation coefficient $\left(\mathrm{r}_{\mathrm{xy}}\right)$ ranges from 0.37 to 0.64 . The Alpha Cronbach coefficient of the 12 test items which states about the reliability of the instrument of critical thinking is 0.79 with high qualification.

\section{Social attitude questionnaire}

the social attitude scale was adapted from the conception of Gardner (1999), Goleman (2000), and Howarth (2006) which covers four main dimensions:1) group organizing attitude, 2) negotiation solution attitude, 3) personal relation maintaining attitude, and 4) attitude in doing a social analysis. The four social attitudes are translated into 30 items of the social attitude instrument. Every item uses a Likert scale by erasing the neutral element so that it has the 1-4 degradation scale. The result of the try-out with 291 subjects showed that the correlation coefficient of the total items of the social attitude 
questionnaire ranges from 0.36 to 0.60 and the reliability of the 30 items is 0.91 with very high qualification.

\section{Spiritual attitude questionnaire}

the spiritual attitude questionnaire uses eight dimensions which are adapted from the subscale and the list of spiritual attitudes and the list of involvement (SAIL) (De Jager Meezenbroek et al., 2012), which consists of 1) meaningfulness 2) trust, 3) acceptance 4) awareness of the current time, 5) care for others, 6) relatedness with nature, 7) transcendent experience, and 8) spiritual activity. The eight dimensions of the spiritual attitude are differentiated into 30 items. Every item uses a Likert scale by erasing the neutral element. Thus it has the 1-4 scale. The result of the try-out with 294 subjects shows that the correlation coefficient of the total items of the spiritual attitude questionnaire ranges from 0.30 to 0.61 with the reliability of the 30 items $=0.84$ with high qualification.

\section{Character questionnaire}

the students' characters consists of 10 dimensions (Suyanto, 2010), namely 1) love for God and all of His creations, 2) autonomy and responsibility, 3) honesty/trustfulness, 4) diplomacy, 5) respect and politeness, 6) generosity, such as helping each other and collaborating, 7) self-confidence and hardworking, 8) leadership and justice, 9) kindness and modesty, 10) tolerance, peacefulness and unity The data on the students' characters which were collected consisted of 18 items of statement, each completed with four degradation options using the $0-4$ scale The description of the $0-4$ degradation scale is as follows. $0=$ disagree, $1=$ does not quite agree, $3=$ agree, $4=$ agree very much. Based on the result of the try-out with 300 students, the Pearson-Product moment correlation of the total items was found to range from $r=0.36$ to $r=0.72$. The reliability index which was determined by Alpha Cronbach coefficient $\alpha=0.80$ with high qualification.

\section{The technique of data analysis}

To test the difference in effect between GI model and EL model on the students' critical thinking skill, social skill, spiritual skill, and character, the data of the study were subjected to the inferential statistical analysis using one-way MANOVA.

\section{RESULTS AND DISCUSSION}

\section{Descriptive Analysis Result}

The result of this descriptive analysis presents the effect of Group Investigation /GI compared to that of EL in attaining 4 (four) dependent variables, namely critical thinking skill, social skill, spiritual skill, and character of the students of SMAN 1 Tabanan and SMAN 1 Kediri Tabanan. The result is shown in TABLE 1.

TABLE 1. Recap of descriptive analysis of the students' critical thinking skill, social attitude, and character in the two treatments

\begin{tabular}{lcrrrcc}
\hline $\begin{array}{l}\text { DEPENDENT } \\
\text { VARIABLE }\end{array}$ & MODEL & MEAN & SD & N & $\begin{array}{c}\text { MEAN } \\
\text { 0-100 Scale }\end{array}$ & Qualification \\
\hline Critical & GI & 36.05 & 5.547 & 70 & 60.08 & Medium \\
& EL & 30.19 & 6.60 & 70 & 50.32 & Low \\
Social & GI & 109.08 & 8.17 & 70 & 91.16 & Very high \\
& EL & 103.39 & 5.86 & 70 & 86.16 & Very high \\
Spiritual & GI & 108.05 & 8.75 & 70 & 90.04 & Very high \\
& EL & 98.07 & 10.21 & 70 & 81.73 & High \\
Character & GI & 66.38 & 4.09 & 70 & 92.19 & Very high \\
& EL & 61.79 & 4.92 & 70 & 85.82 & Very high \\
\hline
\end{tabular}


The result of the descriptive analysis in TABLE 1 shows that descriptively, critical thinking skill, social skill, spiritual attitude, and character attained by the students who learned with GI was higher than their counterparts who learned with EL model. However, qualitatively the difference occurred in the variables of critical thinking and spiritual attitude, while in the variables of social attitude and character, the two models gave the same effect.

\section{Tests of Assumption}

The tests of assumption done covered the normality test of data distribution using KolmogorovSmirnov and Shapiro-Wilk, Box's Test of Equality of Covariance Matrices, and Levine's Test of Equality of Error Variances. The recap of the result of the tests is shown in TABLE 1, TABLE 3, and TABLE 4.

TABLE 2. Recap of the normality test of DV data distribution

\begin{tabular}{lcccccc}
\hline & \multicolumn{3}{c}{ Kolmogorov-Smirnov $^{\mathbf{a}}$} & \multicolumn{3}{c}{ Shapiro-Wilk } \\
\cline { 2 - 7 } DATA SOURCE & Statistic & df & Sig. & Statistic & df & Sig. \\
\hline CRITICAL GI & .117 & 70 & .145 & .956 & 70 & .132 \\
SOCIAL GI & .089 & 70 & .200 & .958 & 70 & .142 \\
SPIRITUAL GI & .093 & 70 & .200 & .945 & 70 & .110 \\
CHARACTER GI & .231 & 70 & .210 & .881 & 70 & .100 \\
CRITICAL EL & .086 & 70 & .200 & .973 & 70 & .224 \\
SOCIAL EL & .118 & 70 & .140 & .972 & 70 & .188 \\
SPIRITUAL EL & .103 & 70 & .185 & .950 & 70 & .116 \\
CHARACTER EL & .139 & 70 & .126 & .938 & 70 & .105 \\
\hline
\end{tabular}

Based on the result of the normality test in TABLE 2 it is apparent that Kolmogorov-Smirnov and Shapiro-Wilk statistical values for each of the four dependent variables shows a higher significance value than 0.05 . Hence, the data of the students' critical thinking skill, social attitude, spiritual attitude, and character have normal distributions.

\begin{tabular}{lr} 
TABLE 3. Box's Test of Equality of Covariance Matrices DV \\
\hline Box's M & 42.342 \\
F & 1.077 \\
df1 & 10 \\
df2 & 64331.474 \\
Sig. & .098 \\
\hline
\end{tabular}

The result of Box's Test of Equality of Covariance Matrices in TABLE 3 shows that $F=1.077$ at sig. $=0.098$ which is greater than 0.05 . This means that the covariance matrices of dependent variables are homogeneous. The result of this test is the assumption of Multivariate Analysis of Covariance.

The recap of the result of Levine's Test of Equality of Error Variances is shown in TABLE 4.

TABLE 4. Levene's Test of Equality of Error Variances DV between Treatment Groups

\begin{tabular}{lcccc}
\hline DEPENDENT VARIABLE & F & df1 & df2 & Sig. \\
\hline CRITICAL & 1.825 & 1 & 138 & .179 \\
SOCIAL & 3.527 & 1 & 138 & .063 \\
SPIRITUAL & 1.393 & 1 & 138 & .240 \\
CHARACTER & 2.546 & 1 & 138 & .087 \\
\hline
\end{tabular}

TABLE 4 shows that Lavine statistical values for each of the dependent variables have a significant value that is greater than 0.05 . Hence, the variances of the two treatment groups, GI and EL were homogeneous.

Based on the results of the analyses it can be concluded that MANOVA assumptions have been met, below in TABLE 5 is presented the result of Multivariate Analysis of Covariance. 


\section{Hypotheses Testing}

TABLE 5. Result of Multivariate Analysis of Covariance

\begin{tabular}{llcccc}
\hline Effect & \multicolumn{1}{c}{ Statistic } & F & Hypothesis df & Error df & Sig. \\
\hline \multirow{3}{*}{ GI v.s EL } & Pillai's Trace & 21.712 & 4.000 & 113.000 & \\
& & & & & .000 \\
& & & & & \\
\cline { 2 - 6 } & Wilks' Lambda & 21.712 & 4.000 & 113.000 & .000 \\
& Hotelling's Trace & 21.712 & 4.000 & 113.000 & .000 \\
& Roy's Largest Root & 21.712 & 4.000 & 113.000 & .000 \\
\hline
\end{tabular}

TABLE 5 shows that the statistical values of Pillai's Trace, Wilks' Lambda, Hotelling's Trace, and Roy's Largest Root respectively are $F=21.712$ at sig. $=0.001$, which is smaller than sig $=0.05$. Hence, the four dependent variables show a significant difference between GI and EL treatments. This result indicates that Tests of Between-Subjects Effects are needed as shown in TABLE 6.

TABLE 6. Results of Tests of Between-Subjects Effects

\begin{tabular}{lcccccc} 
Source & $\begin{array}{c}\text { Dependent } \\
\text { Variable }\end{array}$ & $\begin{array}{c}\text { Type III Sum of } \\
\text { Squares }\end{array}$ & df & Mean Square & F & Sig. \\
\hline MODEL & CRITICAL & 1014.542 & 1 & 1014.542 & 27.294 & .000 \\
& SOCIAL & 956.746 & 1 & 956.746 & 18.943 & .000 \\
& SPIRITUAL & 2940.008 & 1 & 2940.008 & 32.503 & .000 \\
\hline Error & CHARACTER & 617.797 & 1 & 617.797 & 30.170 & .000 \\
& CRITICAL & 4311.797 & 138 & 37.171 & & \\
& SOCIAL & 5858.610 & 138 & 50.505 & & \\
& SPIRITUAL & 10492.576 & 138 & 90.453 & & \\
& CHARACTER & 2375.356 & 138 & 20.477 & & \\
\hline
\end{tabular}

TABLE 7 shows that GI model and EL model significantly have different effects on each of the dependent variables, namely student's critical thinking $(F=27.294 ; p<0.05)$, student's social attitude $(\mathrm{F}=18.943 ; \mathrm{p}<0.05)$, student's spiritual attitude $(\mathrm{F}=32.503 ; \mathrm{p}<0.05)$, and student's character $(\mathrm{F}=$ $30.170 ; \mathrm{p}<0.05)$. Based on TABLE 1, GI treatment is better in attaining the four dependent variables. In GI treatment, student's critical thinking $(\mathrm{M}=36.05 ; \mathrm{SD}=5.55)$ compared to $(\mathrm{M}=30.19 ; \mathrm{SD}=$ 6.60) in EL treatment; student's social attitude in GI, $\mathrm{M}=109.08$; $\mathrm{SD}=8.17$ while and in EL, $\mathrm{M}=$ 103.39; $\mathrm{SD}=5.86$; student's spiritual attitude in $\mathrm{GI}, \mathrm{M}=108.05$; $\mathrm{SD}=8.75$ while in $\mathrm{EL}, \mathrm{M}=98.07$; $\mathrm{SD}=10.21$; and student's character in $\mathrm{GI}, \mathrm{M}=66.37$; $\mathrm{SD}=4.09$ while in $\mathrm{EL}, \mathrm{M}=61.79 ; \mathrm{SD}=$ 4.92 .

This study showed that the GI model as one type of cooperative learning model was better than the EL model in attaining the critical thinking skill, social attitude, spiritual attitude, and good character development of the students who learned physics at SMAN 1 Tabanan and SMAN 1 Kediri Tabanan. The result of this study conforms to the previous findings (AKÇAY \& DOYMUŞ, 2012; Astiti 2018; Parinduri et al., 2017; Sari, 2017; Yuandini \& Sahyar, 2017).

AKÇAY and DOYMUŞ (2012) found that the GI model was better than the conventional teaching model in attaining learning achievement for first-semester college students. In Physics teaching at Class XI SMA (senior high school), it has been proven that the GI model was better than Jigsaw in attaining learning achievement (Astiti 2018). In learning in the concept of temperature and heat in physics, the GI model was better for the attainment of science conceptual understanding and process skill (Parinduri et al., 2017). Sari (2017) also found that GI was better than the conventional teaching model in attaining physics learning achievement at the high school. The same finding was also found for a conceptual understanding of high school (Yuandini dan Sahyar, 2017).

The superiority of the GI model as one type of cooperative learning is caused by the use of a collaborative approach and investigation in the learning process in this model. GI model provides learning activities by giving opportunities to the students to do an investigation in groups which is related to problems that are related to the topic contextually which makes the teaching more studentcentered. GI model can facilitate the students through investigation and discussion activities to determine and decide alternative solutions that are considered the best so that it can help the students 
in developing thinking skills, problem-solving skills, and intellectual skills. Hence, the mastery of the teaching materials will increase and lead to the students' improvement in learning achievement (Sari, 2017).

The implementation of the GI model will actively engage the students in learning in general and in autonomous learning and makes the effect of learning more permanent. The main objective of implementing GI is to give the students responsibility for their learning, and for interacting with one another. The teaching that occurs in GI model provides a learning atmosphere which is characterized with the students listening to each other in their peer group, an activity which is joyful and interesting for them, and this type of learning also motivates them (Doymuş \& Şimşek, 2007 in AKÇAY1 \& DOYMUŞ 2012). Hence, the students are sharing the topic with each other, interact in a different group, correcting their errors together and learn different things very intensively by using a high order thinking skill and collaborative ability based on deep awareness and belief. These competences are fundamental competences in developing the students' attitudes, including good social attitude, good spiritual attitude and character. It is this that has made the students in this study obtain a better social attitude, spiritual attitude and character in the GI model than in the EL model.

Quantitatively, the attainment of critical thinking skills by the students in learning sound waves and lightwave in physics through the GI model has not been optimal. This becomes a challenge in the next study. The less than optimal critical thinking skill was caused by the fact that the students have not been accustomed to using the GI model. The five-meeting treatment has not been able to make thems adapt appropriately and quickly. However, if the GI model had been implemented well and sustainably, the impact on the development of critical thinking skills would have been more optimal. In the attainment of social attitude, spiritual attitude, and character, the study showed a very high qualification in each of the two teaching models. This shows that the EL model has oriented the atmosphere of the class to a more humanistic one. Moreover, the GI model is believed to be a means of developing a more democratic learning community at school. This result should be maintained in the next teaching, both on the same topic and in other topics.

\section{SUMMARY}

The teaching of the sound wave and lightwave in physics using the GI model shows a greater effect significantly compared to the effect of EL model in attaining the students' critical thinking skill, social attitude and character. The teaching with the EL model should be stopped and the GI model should be used sustainably as a means of developing critical thinking skills in physics, developing good a social attitude, and a spiritual attitude, and in building the nation's good character. It would be better if the implementation of the GI model in physics is deliberately designed and implemented by integrating the concept of character education. To this end, the teachers should be supported by the school, the society and the government is doing their duties. This is very important to develop a learning community that is democratic and at the same time to prepare the students to become good family members, community members and citizens.

\section{REFERENCES}

Achmad, W. K. S., Bundu, P., Suradi \& Jufri, M 2018, 'Application of group investigation (GI) learning model in Pendidikan IPS SD course to improve students' critical thinking skills at PGSD Universitas Negeri Makassar', IOSR Journal of Research \& Method in Education (IOSR-JRME), vol. 8, Number 2, pp. 41-46.

Agboola, A \& Tsai, K. C 2012, 'Bring character education into classroom', European Journal Of Educational Research, vol. 1, number 12, pp. 163-170.

Ahsanah, F 2015, 'Group investigation: A cooperative learning method for the 10th grade students in speaking english classroom', TELL Journal, vol. 3, number 1, pp. 57-69. 
AKÇAY1, N. O \& DOYMUŞ, K 2012, 'The effects of group investigation and cooperative learning techniques applied in teaching force and motion subjects on students' academic achievements', Journal of Educational Sciences Research, vol. 2, number 1, pp. 109-123.

Astiti, K. A 2018, 'The effect of group investigation learning model with brainstorming technique on students learning outcomes', SHS Web of Conferences, vol. 42, 00122 (2018) https://doi.org/10.1051/shsconf/ 20184200122.

De Jager Meezenbroek, E., Garssen, B. ., Van Den Berg, M., Tuytel, G., Dierendonck, D. V., Visser, A \& Schaufeli, W. B 2012, 'Measuring spirituality as a universal human experience: Development of the spiritual attitude and involvement list (SAIL)', Journal of Psychosocial Oncology, vol. 30, pp. 141-167.

Dodds, D. M 2016, 'The Effects of Character Education on Social-Emotional Behavior', Retrieved from Sophia, the St. Catherine University repository website: https://sophia.stkate.edu/ maed/137, pp. $1-33$.

Dostál. J 2015, 'The definition of the term Inquiry-based instruction', International Journal of Instruction, vol. 8, number 2, pp. 69-82.

Egan, K 2001, 'Spirituality, education, and the moral life', Paper, delivered to the AERA conference held in Seattle, WA, on April 10-14.

Ennis, R. H 2013, 'The nature of critical thinking: Outlines of general critical thinking dispositions', Online article. http://criticalthinking.net/wp-content/uploads/2018/01/ The-Nature-of-CriticalThinking.pdf.

Fathurahman, P 2012, 'Model of the character education in developing countries', Journal of Applied Sciences Research, vo. 8, no. 3, pp. 1813-1816.

Gardner, H. "The dicipline mind: What all students should understand", (Simon \& Schuster Inc, New York, 1999).

Goleman, D. "Emotional intelligence" (PT Gramedia Pustaka Utama, Jakarta, 2000).

Heinich, R., Molenda, M., Russell, J. D \& Smaldino, S. E. "Instructional media and technology for learning, $7^{\text {th }}$ edition" (Prentice Hall, Inc, New Jersey, 2002).

Howarth, C 2006, 'How social representations of attitudes have informed attitude theories: The consensual and the reified', Theory and Psychology, vol. 16, number 5, pp. 691-714.

Indarti, D., Mardiyana \& Pramudya, I 2017, 'Group investigation with scientific approach in mathematics learning', International Conference on Mathematics, Science and Education 2017 (ICMSE2017), IOP Conf. Series: Journal of Physics: Conf. Series 983 (2018) 012147 DOI:10.1088/1742-6596/983/1/012147.

Iswardati 2016, 'The implementation of group investigation to improve the students' speaking skill', Dinamika Ilmu, vol. 16, number 2, pp. 245-261.

Luke. A 2014, 'On explicit and direct instruction', Australian Literacy Educator's Association, More alea 'hot topics' at www.alea.edu.au.

Parinduri, S. H., Sirait, M \& Sani, R. A 2017, 'The effect of cooperative learning model type group investigation for student's conceptual knowledge and science process skills', IOSR Journal of Research \& Method in Education (IOSR-JRME), vol. 7, number 4, pp. 49-54.

Pitoyo, A., Waluyo, H. J., Suwandi, S \& Andayani, 2014, 'The effect of group investigation learning model, accelerated team and role playing on elementary school students' writing skills viewed from cognitive style', Journal of Education and Practice, vol. 5, number 1, pp. 21-29.

Raka, G., Mulyana, Y., Markam, S. S., Semiawan, C. R., Hasan, S. H., Bastaman, H. D \& Nuracham, N. "Pendidikan karakter di sekolah: Dari gagasan ke tindakan" (Elex Media Komputindo, Jakarta, 2011). 
Sari, E 2017, 'Pengaruh model pembelajaran kooperatif tipe group investigation terhadap hasil belajar fisika ditinjau dati kemampuan berpikir logis', Jurnal Pendidikan Fisika, vol. 6, number 1, pp. 27 32.

Santyasa, I W. "Asesmen dan evaluasi pembelajaran fisika" (Graha Ilmu, Yogyakarta, 2014).

Santyasa, I W. "Pembelajaran inovatif” (Undiksha Pres, Singaraja, 2017).

Santyasa, I W \& Suwindra, I N. P 2009, 'Pengembangan pemahaman konsep dan kemampuan pemecahan masalah fisika bagi siswa SMA dengan pemberdayaan model perubahan konseptual berseting investigasi kelompok', Jurnal Penelitian dan Pengembangan Pendidikan, vol. 3, number 1, pp. 1-16.

Siddiqui, M. H 2013, 'Group investigation model of teaching: Enhancing learning level', Paripex Indian Journal Of Research, vol. 3, number 4, pp. 78-80.

Slavin, R. E. “Cooperative learning, $2^{\text {nd }}$ edition” (Allyn and Bacon, Boston, 1995).

Suyanto 2000, 'Urgensi pendidikan karakter', http://waskitamandiribk.wordpress.com/2010/06/02/urgensipendidikan-karakter/.

Yahya Khan, D. "Pendidikan karakter berbasis potensi diri mendongkrak kualitas pendidikan" (Pelangi, Yogyakarta, 2010).

Yuandini, F \& Sahyar 2017, 'The effect of cooperative learning model type group investigation assisted flash media, scientific attitude on students' conceptual knowledge', Journal of Education and Practice, vol. 8, number 17, pp. 150-155. 
